\title{
Transformações e permanências do movimento peronista na Argentina
}

Raquel Fernandes Lanzoni ${ }^{1}$

SEBRELI, Juan José. Los deseos imaginarios del peronismo. Ciudad Autónoma de Buenos Aires: Sudamericana, 2019.

Resenha recebida em: 10/05/2020

Resenha aprovada para publicação em: 19/06/2020

O livro Los deseos imaginarios del peronismo do filósofo e historiador argentino Juan José Sebreli, publicado originalmente em 1983, no contexto da última ditadura militar (1976-1983), tornou-se uma referência clássica para os estudos acerca do peronismo e para a compreensão tanto de suas raízes ideológicas quanto de suas vinculações, semelhanças e diferenças em relação, principalmente, ao fascismo e o populismo. Em decorrência de seu sucesso, o livro foi reeditado em 1992. Em 2019 passou por outra revisão/atualização, na qual Sebreli inseriu dois elementos de análise e discussão substanciais para a compreensão do cenário político argentino no tempo presente: o menemismo e o kirchnerismo. A atualização da obra fundamental de Sebreli é justificada pelo intento de contribuir para compreensão da "batalha cultural" entre os binômios democracia/liberdade e populismo/autoritarismo que, desde o século passado, atingem algumas regiões da América Latina até os dias atuais.

Composto por sete capítulos e quatro apêndices, o objetivo norteador do livro é discutir o caráter fascista do peronismo, identificado na atuação e influência de Perón em determinadas áreas da sociedade, como a classe obrera, grupos da sociedade civil e a classe média. Para isso, Sebreli antes se dedica à análise de movimentos anteriores ao peronismo, como o bonapartismo e o próprio fascismo. Questiona-se, todavia, se a

\footnotetext{
${ }^{1}$ Graduada pela Universidade Estadual de Londrina (UEL) e mestranda pelo Programa de Pós Graduação em História da Universidade Estadual Júlio de Mesquita Filho (UNESP/Assis) com a pesquisa "Propaganda política em Mundo Peronista (1951-1955)”. E-mail: raquelflanzoni@gmail.com.
} 
comparação entre o peronismo e outros movimentos surgidos em lugares e períodos diferentes seria válida para a História.

O peronismo - assim como qualquer outro acontecimento histórico - deve ser analisado a partir de sua própria perspectiva, pois os episódios, na História, não se repetem. Entretanto, o autor argumenta a favor da comparação ao inferir que não é possível pensar em formas culturais e políticas totalmente independentes, pois mesmo no interior dos acontecimentos considerados mais singulares é possível encontrar pontos comuns e constantes com outras realidades. O que interessa ao historiador é o geral e o universal no individual e, assim, "[...] lo que permite comprender el papel histórico jugado por Perón son conceptos generales tales como su clase de origen, la situación histórica y la época que le tocó vivir, su pertenencia a las Fuerzas Armadas, su ideología" (SEBRELI, 2019, p. 29).

Em relação aos traços bonapartistas e fascistas identificáveis no peronismo, ambos referem-se à capacidade de mobilização das massas e do apoio destas ao líder político, como sublinha o autor. As características bonapartistas ${ }^{2}$ são distinguidas na sustentação do Estado a partir de três instituições básicas: a Igreja, o Exército e a polícia. Quanto à Igreja, é sabido que a instituição católica aliou-se a J. Perón ainda durante a campanha eleitoral, pois enxergava o peronismo como um meio de conter o avanço do socialismo e do comunismo nos meios sindicais. Ademais, como indicou Loris Zanatta (1999), J. Perón despertava a esperança de que finalmente o projeto de "nação católica" gestado anteriormente nos anos 1930 por intelectuais católicos seria alcançado mediante a aliança com o líder justicialista.

Em relação ao Exército, a formação militar de J. Perón e sua participação no golpe militar de 1943 não deixam dúvidas quanto à estreita ligação entre o governo peronista e

\footnotetext{
${ }^{2} \mathrm{O}$ bonapartismo consiste, sumariamente, em um político que, mesmo eleito democraticamente, apresenta tendências autoritárias em seu discurso e ações, além de operar a integração das massas populares na sociedade estabelecida. Nas palavras de Sebreli, "el papel doble jugado por el bonapartismo peronista consistía en presentarse la clase trabajadora como portavoz de sus reclamos a la burguesía, haciéndole sentir a ésta la presión de las masas detrás de ella, pero a la vez ofrecerse a la burguesía como el único capacitado para frenar a las masas y evitar el desborde, y, por lo tanto, el verdadero protector de las clases burguesas contra las masas, como el defensor del capitalismo ante la posible revolución social, el 'cataclismo social' en términos de Perón' (2019, p. 57).
} 
as Forças Armadas. Mesmo com as eleições democráticas de 1946, Sebreli indica que Perón representava o candidato escolhido pelo Grupo de Oficiais Unidos (GOU) como uma última tentativa de salvar o governo militar em grande medida desprestigiado na sociedade argentina. Durante todo seu governo, os militares exerceram considerável influência nas decisões políticas de J. Perón. Quando ocorreu a tentativa de lançar a chapa Perón/Perón nas eleições de 1951, Eva Perón foi forçada a renunciar à candidatura ao cargo da vice-presidência por conta da pressão exercida pelos militares. No que diz respeito ao último elemento, o autor destaca que as tropas policiais eram compostas em sua maioria por peronistas. $\mathrm{O}$ interesse no controle policial residia justamente na manutenção da ordem e na contenção de manifestações da oposição.

Apesar de sustentar - e justificar - durante todo o decorrer do livro as semelhanças entre peronismo e fascismo, a aproximação entre os dois movimentos não foi, todavia, inaugurada por Sebreli. Ainda década de 1940, alguns intelectuais e políticos pertencentes às denominações socialistas, comunistas, radicalistas e até mesmo grupos conservadores, interpretavam o peronismo como um movimento nazifascista, o que o tornava um "mero reflexo da sociedade europeia". A tentativa de construir uma sociedade harmônica - ou pelo menos a imagem dela - demandou não só um maior controle do Estado, mas também o desenvolvimento de estratégias políticas paralelas. A construção da figura do líder como protetor das massas, o intenso uso dos meios propagandísticos para a divulgação e legitimação do movimento, a concessão de direitos trabalhistas e a ampliação do Estado de Bem-Estar são alguns exemplos que permitem tecer analogias entre fascismo e peronismo concomitantes, também, com medidas de censura à oposição e a repressão de greves de trabalhadores que não estavam alinhados com os sindicatos reconhecidos pelo governo.

Essas características totalitárias do peronismo são confirmadas não somente por Sebreli, mas por Capelato (2009), que também se dirige à mesma linha de interpretação. Ademais das confluências internas, J. Perón não escondia a admiração que possuía por Benito Mussolini em visita à Itália fascista no início da década de 1940. Entretanto, não cabe caracterizar o peronismo como um regime totalitário, pois não houve, de acordo com 
o autor, a eliminação da influência de outros poderes e setores da sociedade, como os partidos políticos, as classes dominantes, a Igreja e o Exército. Nesse âmbito, Capelato argumenta que apenas em níveis de propaganda é possível encontrar traços totalitários no peronismo, mas que o conceito em si não se aplica a nenhuma realidade latino-americana.

A incorporação das discussões acerca do menemismo e do kirchnerismo são o que de fato atualizam Los deseos imaginarios del peronismo. Vistos em certa medida como continuações do peronismo, os movimentos - representados por Carlos Menem e Néstor e Cristina Kirchner - destacam-se também por propostas que se distanciavam do peronismo clássico. Carlos Menem (1989-1999) assumiu o país após a presidência de Raul Alfonsín (1983-1989) e deu continuidade à desmilitarização da sociedade argentina iniciada no governo anterior, resultando na subordinação das Forças Armadas ao poder civil, o que simbolizou a ruptura de uma das alianças mais caras ao peronismo. Outrossim, as circunstâncias críticas sobre as quais assumiu o poder, somadas à diferente percepção de realidade que possuía em relação a J. Perón demonstram, para Sebreli (2019, p. 291), que Menem, mesmo tendo sido eleito pelo Partido Justicialista, incumbiu-se da tarefa de "destruir o peronismo clássico em nome do próprio peronismo".

Mais problemático ainda para o autor por conta da aproximação ao populismo, o kirchnerismo inaugurou na história argentina o período conhecido como neopopulismo. Segundo Sebreli, os governos presidenciais dos Kirchner aproximavam-se mais do peronismo clássico que o menemismo, tanto por conta do viés populista, quanto pelo reaparecimento das características bonapartistas. O "semibonapartismo" do kirchnerismo é explicado por uma liderança autoritária e personalista, um maior controle do Congresso e do Poder Judiciário pelo Poder Executivo, ao passo que a ausência de apoio de instituições mais tradicionais como a Igreja e o Exército, outrora presentes no peronismo clássico, não permite atribuir aos governos de Néstor (2003-2007) e Cristina (2007-2015) um bonapartismo absoluto, como ressalta o autor. No plano econômico e político, os governos se assemelharam ao peronismo, principalmente no tocante à modernização progressista naquele período, como o matrimônio igualitário, ao mesmo tempo em que assumiam posicionamentos que se contradiziam, como a oposição à legalização do 
aborto $^{3}$. Essa incoerência é similarmente observada no final do segundo governo de J. Perón, quando, por intenção de somente desagradar a Igreja, o líder peronista atendia reinvindicações como o ensino laico e o direto ao divórcio.

Recuperando a frase que Karl Marx atribuiu a Luis Bonaparte, Sebreli (2019, p. 296) serviu-se desta para também caracterizar Nestór Kirchner: "No es nadie y por eso puede representarlos a todos". Grupos aliados o localizavam como um político de centroesquerda, enquanto grupos opositores tal quais os trotskistas o chamavam de "capitalista selvagem" e fascista. O próprio Néstor, entretanto, não se definia nem à esquerda e nem à direta da política. A defesa do nacional e do popular permite ao autor categorizá-lo na qualidade de um populista - ainda que ele não se reconhecesse como tal -, inclinando-se ao "neopopulismo latino-americano" ao estilo de Hugo Chávez, Evo Morales, Fidel Castro, entre outros. Já o governo de Cristina se aproximou de um "semifascismo a maneira de Chávez", principalmente em seus anos finais, quando a presidente empreendeu medidas políticas que fomentavam ainda mais o populismo: politização do futebol, a realização de discursos transmitidos pelas rádios desde o balcão da Casa Rosada e o reconhecimento do coletivo Madres de la Plaza de Mayo como importante defensor dos direitos humanos.

A obra de Juan José Sebreli se configura, indubitavelmente, como um clássico para os estudos sobre o peronismo. Sua densidade de informações é acentuada por uma construção textual descomplicada que carrega, ao mesmo tempo, traços de erudição que realçam a importância da referida obra. O levantamento de fontes e de bibliografia feito pelo autor também é um ponto de merecido destaque: o diálogo entre trabalhos publicados à época do peronismo e aqueles feitos posteriormente contribuem para a percepção de mudanças interpretativas em relação ao movimento. O "peronismo depois de Perón” ainda encontra um terreno tão fértil para a sua sobrevivência e manutenção que as eleições de 2019 receberam holofotes do mundo inteiro devido à possibilidade real de um candidato peronista retornar à presidência do país. Para Sebreli, o momento de

\footnotetext{
${ }^{3}$ Neste ponto, é válido ressaltar que Cristina foi mais enfática na crítica à legalização do aborto que Néstor. 
"encruzilhada" vivida com profunda tensão pelos argentinos não representava somente uma mudança de governo, mas, assim como em 1983, uma mudança de sistema.

O ponto mais controverso da obra, que naturalmente alarga as bases para uma discussão mais aprofundada, é a incessante tentativa de aproximação entre peronismo e fascismo por parte do autor. A transposição de elementos próprios de uma sociedade historicamente localizada para outra, em alguns casos, pode implicar em anacronismos ou leituras forçadas. É válida, como já pontuada anteriormente, a comparação entre duas realidades, já que podem trazer benefícios para o trabalho do historiador, mas se deve prezar para que não se caia em justaposições e classificações (PRADO, 2005) que tentem ajustar as realidades analisadas a um modelo já existente (BARROS, 2007).

$\mathrm{Na}$ análise de Hélgio Trindade (2000) sobre a presença do fascismo e do neofascismo na América Latina, apesar do peronismo carregar traços totalitários que o assemelham ao fascismo - como a sua base de apoio ser composta inicialmente por grupos ligados a setores militares e clericais defensores de um nacionalismo exacerbado -, o autor sublinha que o movimento se aproxima mais de uma vertente nacional-popular, não muito distante do movimento liberal-popular protagonizado anteriormente pelos grupos radicais no cenário político argentino. Ademais, enquanto o Estado fascista se impunha "de cima para baixo" exercendo uma repressão das elites em relação à classe trabalhadora, o peronismo não encontrou apoio suficiente nas classes altas e grupos empresariais da época, estando ligado impreterivelmente à mobilização das massas.

Ancorando-se em Di Tella, Trindade sustenta que as constituições sociais dos fenômenos fascista e peronista foram diferentes: no primeiro, o apoio maior precedia das baixas classes médias, ao passo que no peronismo a base de apoio era composta em sua maioria pela classe operária. Acrescenta ainda que os governos de Perón foram profundamente antagonizados pelas classes altas; em contrapartida, na Itália fascista, a elite pouco temia o avanço do fascismo, fazendo-lhe fraca oposição.

Desse modo, a linha de interpretação que sustenta o peronismo como um movimento fascista não encontra argumentações sólidas o bastante para efetivar esse pensamento. A presença de traços semelhantes com os do fascismo é identificada 
principalmente na década de 1940, nos grupos da base de apoio a Perón, no uso da propaganda política para a difusão e legitimação do movimento, mas não justifica o enquadramento do peronismo na categoria de movimento fascista. Quando Sebreli dedica um capítulo inteiro à discussão de um "fascismo de esquerda", objetivando esclarecer ao leitor que em cada país o fascismo adota formas peculiares, toca em ponto muito caro à historiografia atual. A História vem sendo constantemente usada como arma política para legitimar posicionamentos ultraconservadores e reacionários, nos quais o racismo, a xenofobia e o machismo são naturalizados.

Os negacionismos históricos - que consistem em construções ideológicas e não históricas - recusam acontecimentos que marcaram profundamente as sociedades do mundo todo, como o holocausto nazista e a escravidão africana, e se empenham na deturpação dos fatos, cuja intenção é a criação de uma visão distorcida da História que legitime projetos políticos. Essa discussão nos leva a outro conceito conhecido na historiografia: o revisionismo. Para Adam Schaff (1995), a ideia mecanicista de uma história "pronta" e "encerrada" é contestada a partir do pressuposto presentista de que a história nunca é acabada e nunca será possível escrever toda a história, uma vez que ela se configura como um produto das indagações do presente.

Semelhantemente, Antoine Prost pontua que o historiador nunca conseguirá esgotar completamente seus documentos, nem as possibilidades de questões levantadas por eles. Partindo de diferentes questionamentos e utilizando outros métodos, o historiador constitui novos aspectos da realidade acessível em documentos. "As questões encadeiam-se umas nas outras, geram-se mutuamente" (PROST, 2008, p. 79), fazendo com que a pesquisa histórica seja reintroduzida. Em vista da impossibilidade de encerramento das questões históricas, a história está fadada a ser continuamente reescrita. Como nos indica Bruno Leal Pastor de Carvalho (2016, p. 7), "é precisamente por conta dessa dimensão epistemológica da historiografia que os negacionistas reclamam o rótulo de 'revisionistas"”. Todavia, o revisionismo ideológico, aquele que se alinha aos negacionismos, não visa à ampliação dos conhecimentos sobre o passado, mas à sua distorção e destruição. Portanto, a aproximação entre fascismo e a esquerda feita por 
Sebreli torna-se perigosa, uma vez que pode deixar espaços para que pensamentos como esse sejam estimulados e fomentem discussões que defendam uma possível reabilitação do fascismo como alternativa política.

É necessário, portanto, discernir os momentos nos quais o autor propõe uma interpretação arriscada acerca do peronismo, sobretudo quando o compara aos regimes totalitários europeus do século XX. Ao mesmo tempo, a leitura de Los deseos imaginarios del peronismo muito tem a contribuir para o conhecimento mais profundo do peronismo clássico e fornece ao leitor, a partir da versão atualizada de 2019, um panorama para compreender a influência do movimento ainda em voga na Argentina. A publicação da obra, com a atualização conceitual sobre kirchnerismo, contribuirá para a reflexão do tempo presente no âmbito do governo de Alberto Fernández e Cristina Kirchner, suas semelhanças e distanciamentos com esse projeto de desenvolvimento nacional, há tempos presente na Argentina. A vitória de Fernández foi noticiada na mídia argentina e internacional como a "volta do peronismo", o que dividiu opiniões e gerou diversas especulações acerca dos posicionamentos que o advogado portenho tomaria em relação, principalmente, à economia do país, que se encontra em recessão e com uma inflação acima dos $50 \%$ anuais.

Nesse sentido, os estudos cujos objetos são os governos de Juan Perón não podem se desvincular dessa permanência - transformada e ressignificada ao longo dos anos que o movimento mantém com a sociedade, pois esses trabalhos podem orientar o presente de forma a contribuírem para a compreensão desse profundo marco na história argentina que é o peronismo.

\section{Referências Bibliográficas}

BARROS, José D’Assunção. História comparada - da contribuição de Marc Bloch à constituição de um moderno campo historiográfico. História Social, Campinas, n. 13, pp. 07-21, 2007. Disponível em: https://www.ifch.unicamp.br/ojs/index.php/rhs/article/view/207/199>. Acesso em: 30 abr. 2020.

CAPELATO, Maria Helena Rolim. Multidões em cena: propaganda política no varguismo e peronisrno. Campinas: Papirus, 2009. 
CARVALHO, Bruno Leal de Pastor. O negacionismo do Holocausto na internet: o caso da "Metapédia - a enciclopédia al-ternativa". Faces da História, Assis-SP, v.3, n¹, p. 523, jan.-jun, 2016. Disponível em: http://seer.assis.unesp.br/index.php/facesdahistoria/article/view/303>. Acesso em: 30 abr. 2020.

PRADO, Maria Ligia Coelho. Repensando a história comparada da América Latina. Revista de História, Brasil, n. 153, p. 11-33, dec. 2005.

PROST, Antoine. Doze lições para a história. Belo Horizonte: Autêntica Editora, 2008.

SCHAFF, Adam. Duas concepções da ciência da história: o positivismo e o presentismo. In: História e verdade. São Paulo: Martins Fontes, 1995, p. 101-140.

TRINDADE, Hélgio. Fascismo e neofascismo na América Latina. In: MILMAN, Luis; VIZENTINI, Paulo Fagundes. Neonazismo, negacionismo e extremismo político. Rio Grande do Sul: Editora da UFRGS, 2000.

ZANATTA, Loris. Perón y el mito de la nación católica: Iglesia y Ejército en los orígenes del peronismo. Buenos Aires: Editorial Sudamericana, 1999. 